\title{
Actionable Inaction: Section 1983 Liability for Failure to Act
}

Section 1983 of the Civil Rights Act of 1871 creates a federal cause of action against state officials who deprive private citizens of their constitutional rights. ${ }^{1}$ Increasingly, courts have attempted to define the circumstances under which a state may be held liable for its failure to act to prevent a particular deprivation. ${ }^{2}$ Holding a state liable for its inaction in effect imposes upon it an affirmative duty of protection. Recognizing this, most courts have not imposed affirmative duties on the states; they view the Constitution as, principally, a "charter of negative liberties"3 designed to prohibit certain state actions rather than mandating them.

The first section of this comment will examine the current case law. Most courts have held that a state must take action to protect an individual only when there exists a "special relationship" between the state and that individual. In attempting to define the requisite special relationship, the courts have adopted two distinct modes of analysis, both borrowed from the common law of tort. One approach focuses on whether the state caused the harm to the individual, the other on whether the state had a duty to protect the injured person.

Part II argues that these approaches are misguided. The concept of special relationship fails to provide a viable constitutional basis for the obligation to protect citizens. It is incorrect to resolve these "failure to act" cases on the basis of general theories of tort

142 U.S.C. \& 1983 (1982).

${ }^{2}$ For the sake of convenience, this comment uniformly refers to the party being sued as the "state," even though states, government agents, and municipalities all may be defendants under section 1983. Of course, a state itself cannot be liable for damages under section 1983 because of the eleventh amendment. U.S. ConST. amend. XI; see also Hans v. Louisiana, 134 U.S. 1, 21 (1890); Hollingsworth v. Virginia, 3 U.S. (3 Dall.) 378, 381 (1798). The conduct of state officials, however, may make them personally liable for damages in a suit under section 1983, see Monroe v. Pape, 365 U.S. 167, 172 (1961), or may provide the basis for an injunction against the state, see Ex Parte Young, 209 U.S. 123, 159-60 (1908); cf. Edelman v. Jordan, 415 U.S. 651, 663-71 (1974) (disallowing injunctive relief with retroactive effects on the state treasury). Municipalities may also be sued under section 1983, where the complaint alleges that the execution of a "policy or custom" of the municipality led to the injury in question. See Monell v. Department of Social Servs., 436 U.S. 658, 694 (1978).

${ }^{3}$ Bowers v. DeVito, 686 F.2d 616, 618 (7th Cir. 1982), 
liability. Conceptions of causation and duty derived from the common law do not necessarily apply to the deprivations of constitutional rights that are actionable under section 1983 . It is equally inappropriate to resolve state inaction cases by simply asserting that the states have no general duty to provide basic services in the first instance.

By drawing an analogy to recognized "property" entitlements, Part III provides a more appropriate constitutional basis for analyzing state inaction cases. These cases are best understood within the larger context of state action; they consist of the failure to render a service or confer a benefit in a particular case where that service or benefit has already been provided on a general basis to the community. Once services or benefits have been conferred generally, the state's authority to withhold them in a particular instance should be governed by the due process clause. If the service or benefit is a "property" interest, then the due process clause commands that the state may not withhold it without providing procedural protections. ${ }^{4}$

\section{Current Case law}

\section{A. Special Relationships}

Section 1983 of the Civil Rights Act of 1871 renders individuals in state government liable when they deprive citizens of "any rights, privileges or immunities secured by the Constitution and laws." 3 Consequently, the first step in a section 1983 claim is to "isolat[e] the particular constitutional infringement complained

- See, e.g., Goldberg v. Kelly, 397 U.S. 254 (1970) (state must provide evidentiary hearing before federal assistance is terminated).

B 42 U.S.C. $\$ 1983$ (1982). This provision, enacted as section 1979 of the Civil Rights Act of 1871, was originally a part of the general civil rights legislation passed by Congress after the Civil War in an effort to give substantive freedom to the emancipated slaves. See, e.g., Slaughter-House Cases, 83 U.S. (16 Wall.) 36, 71 (1873) (noting that the "one pervading purpose" of the thirteenth, fourteenth, and fifteenth amendments was "the freedom of the slave race, the security and firm establishment of that freedom, and the protection of the newly-made freeman and citizen from the oppressions of those who had formerly exercised unlimited dominion over him").

A section 1983 plaintiff must also show that the defendant was an individual who acted under color of state law. See 42 U.S.C. $\$ 1983$ (1982). Generally, this condition is satisfied if the individual's conduct would constitute "state action" for the purposes of the fourteenth amendment. See Lugar v. Edmondson Oil Co., 457 U.S. 922, 935 (1982) ("If the challenged conduct of respondents constitutes state action as delimited by our prior decisions, then that conduct was also action under color of state law and will support a suit under § 1983."); see also Griffin v. Maryland, 378 U.S. 130, 135 (1964) (action of one who possesses state authority and purports to act according to that authority is state action even if not authorized under state law, and may violate the equal protection clause). 
of." It is this task that makes inaction claims perplexing: can the failure of the state to prevent harm to one of its citizens constitute a constitutional violation?

One way to answer this question would be to define the state's constitutional duties by common law tort principles. In other words, the state actor would be held to violate a citizen's constitutional rights, and thus be subject to section 1983 liability, if his conduct would be considered a tort under state law. Hence, where tort law would impose liability on the individual for his failure to prevent harm to another, section 1983 would do so as well.

Generally speaking, however, state tort law principles do not determine the kinds of conduct that will give rise to a cause of action under section 1983.7 Two recent decisions of the Supreme Court reaffirmed this principle, holding that merely negligent conduct by state officials can never be a constitutional violation, even though it may give rise to state tort liabilities. ${ }^{8}$ Section 1983 simply does not render every tort committed by a state official, even when she is acting in an official capacity, a violation of the Constitution. ${ }^{9}$ Instead, section 1983 renders every state violation of the Constitu-

- Martinez v. California, 444 U.S. 277, 284 n.9 (1980).

7 Paul v. Davis, 424 U.S. 693, 712 (1976) ("interest in reputation is simply one of a number [of things] which the State may protect against injury by virtue of its tort law"). It should be noted that the principles underlying actions brought under the Federal Tort Claims Act ("FTCA"), 28 U.S.C. $\$ \$ 2671-80$ (1982), may to some extent overlap with the principles that underlie section 1983 actions. There are, however, two important differences. First, actions under the FTCA are limited to those in which the United States government has consented to being sued. Id. $\$ 2674$; see also id. $\S 2680$ (listing exceptions to general consent). Second, the FTCA applies only to the conduct of federal officials; the conduct of state officials is not actionable under the statute. See id. § 2671 (defining "employees" whose activities may give rise to a cause of action as federal employees). Thus, the two actions are completely separate; although the principles of the two actions may overlap in some part, they do so only by coincidence.

${ }^{8}$ See Davidson v. Cannon, 106 S. Ct. 668, 670 (1986); Daniels v. Williams, 106 S. Ct. 662,663 (1986). Many of the cases discussed in this comment involve allegations of merely negligent failure to act, for which recovery would now be denied after the Supreme Court's decisions in these two cases. Daniels and Davidson do not affect the principles discussed in this comment, although they may reduce the number of cases to which these principles apply. This comment is concerned with the circumstances under which a duty may arise, and not with the scope of that duty once it is found. Moreover, it is likely that future claimants will frame their allegations in terms of recklessness or deliberate indifference, mental states which the Court has not found insufficient to establish liability under section 1983. The issue of whether recklessness or gross negligence would be sufficient to create a cause of action under section 1983 was left undecided by the Court. See Daniels, 106 S. Ct. at 667 n.3. The Court did, however, cite Estelle with approval, id. at 664, which had held that "deliberate indifference" to eighth amendment rights was sufficient to create section 1983 liability, see 429 U.S. at 103-04.

- See, e.g., Paul, 424 U.S. at 701 (section 1983 is not a "font of tort law to be superimposed upon whatever systems may already be administered by the States"). 
tion actionable; it contains no substantive prohibitions of its own. Even though section 1983 is not entirely congruent with state tort principles, courts have invoked the tort concept of "special relationship" to decide when a state has an affirmative duty to act.10 Courts uniformly agree that recovery for a state's failure to act is appropriate in some cases in which a "special relationship" exists between the state and an individual." Just as tort law recognizes no general affirmative duty to aid others, ${ }^{12}$ courts applying section 1983 recognize no general government duty to provide services. ${ }^{13}$ But just as a tort duty may arise when a person stands in a "special relationship" to the person who needs help, ${ }^{14}$ so too, courts have held, may a constitutional duty arise from such a relationship between the state and an individual. Hence, even the Seventh Circuit, which has taken a very limited view of affirmative constitutional duties, concedes that certain state actions create relationships that can trigger section 1983 liability. ${ }^{15}$

Courts also look to tort law for the factors that indicate whether a special relationship exists: foreseeability of harm to the claimant; ${ }^{16}$ the perpetrator's status as an agent of the state; $;^{17}$ the state's declared intention to protect a certain class of individuals, ${ }^{18}$ and reliance by an individual on implied or express promises of protection by the state. ${ }^{19}$ These various factors represent two distinct tort theories of liability. Some, like agency status, are con-

10 See generally W. Keeton, D. Dobrs, R. Keeton \& D. Owen, Prosser and Keeton on THE LAW OF TORTS $\$ 56$ (5th ed. 1984) (describing the traditional distinction between misfeasance and nonfeasance, discussing the traditional reluctance to grant recovery on the basis of nonfeasance alone, and noting that "special relationships" may give rise to an affirmative duty to act).

" See Jensen v. Conrad, 747 F.2d 185, 190-94 (4th Cir. 1984) (tracing development of "special relationship" doctrine for state inaction liability), cert. denied, $105 \mathrm{~S}$. Ct. 1754 (1985).

12 See, e.g., Yania v. Bigan, $397 \mathrm{~Pa} .316,155$ A.2d 343 (1959) (defendant has no duty to rescue even where he cajoled his neighbor into jumping into a trench full of water, where the neighbor then drowned).

13 See, e.g., Bowers v. Devito, 686 F.2d 616, 618 (7th Cir. 1982).

14 See generally W. KeEton, D. DobBs, R. KeEton \& D. OWEN, supra note 10, 56.

1s See Bowers, 686 F.2d at 618. After noting that "[t]he Constitution is a charter of negative liberties," Judge Posner nevertheless declared that "[i]f the state puts a man in a position of danger from private persons and then fails to protect him, it will not be heard to say that its role was merely passive; it is as much an active tortfeasor as if it had thrown him into a snake pit." This "position of danger" test operates exactly as a "special relationship" to expose the state to section 1983 liability for failure to act.

16 See, e.g., Jensen v. Conrad, 747 F.2d 185, 194 n.11 (4th Cir. 1984), cert. denied, 105 S. Ct. 1754 (1985).

${ }_{17}$ See, e.g., Martinez v. California, 444 U.S. 277, 285 (1980).

18 See, e.g., Jensen, 747 F.2d at 194 n.11.

19 See, e.g., P.L.C. v. Housing Authority, 588 F. Supp. 961, 965 (W.D. Pa. 1984). 
cerned primarily with whether the state was the proximate cause of the harm. Others, like a declared intention to protect, reflect a conception of obligation: did the state have a duty to protect the injured party? Various courts have emphasized each of these theoretical bases for special relationships; as a result, they have differed about when state inaction may violate the Constitution. Some courts argue that liability exists when the state was the proximate cause of the harm. ${ }^{20} \mathrm{~A}$ majority of the courts, however, suggest that a special relationship-and hence liability-arises from the state's duty to protect the injured individual. ${ }^{21}$

1. Proximate Causation. Martinez v. California ${ }^{22}$ demonstrates the importance of proximate cause in state inaction cases. There the Supreme Court considered a claim for section 1983 relief brought by the parents of a girl who had been murdered by a paroled sex offender. ${ }^{23}$ The parents asserted that the state's release of the murderer caused their daughter to be deprived of her life without due process of law. Emphasizing the fact that "the parole board was not aware that appellants' decedent, as distinguished from the public at large, faced any special danger,"24 the Court held that the injury was "too remote a consequence" of the related state action to hold the state responsible. ${ }^{25}$ The Court reasoned that the only aggressive state action was the decision of the parole board to release the murderer. The Court further supported its decision by noting that five months had elapsed since the assailant's release and concluded that the parolee was "in no sense an agent of the [state]."26

${ }^{20}$ See, e.g., Humann v. Wilson, 696 F.2d 783, 784 (10th Cir. 1983).

${ }^{21}$ See, e.g., Jensen, 747 F.2d at 191-94 (citing cases).

22444 U.S. 277 (1980).

2s $I d$. at $279-81$.

24 Id. at 285. Although the Court did not explicitly discuss the concept of a "special relationship," its reference to knowledge of a "special danger" has prompted the courts' interest in special relationships. See, e.g., Fox v. Custis, 712 F.2d 84, 88 (4th Cir. 1983). Although subsequent cases emphasizing "special relationships" in section 1983 suits have dealt explicitly with state inaction, see, e.g., Fox, 712 F.2d at 84, the issue of the state's failure to supervise the parolee after his release was not before the Supreme Court in Martinez, see 444 U.S. at 280 n.2.

${ }^{25}$ Martinez, 444 U.S. at 285. The Court did not explain why it based its decision on the tort concept of causation rather than on duty. Indeed, the Court made only a single reference to "duty" while describing the plaintiff"s potential claims under state tort law. Id. ("Regardless of whether, as a matter of state tort law, the parole board could be said either to have had a 'duty' to avoid harm to his victim or to have proximately caused her death, ... we hold that, taking these particular allegations as true, appellees did not 'deprive' appellants' decedent of life within the meaning of the Fourteenth Amendment.").

${ }^{28}$ Id. The Court in Martinez expressly refused to hold that a parole board could never be held liable for its decision to release a dangerous parolee. Id. 
Following the Supreme Court's lead, several courts have ruled that the lack of a special relationship between the state and the plaintiff precludes recovery under section 1983 for failure to act unless the plaintiff establishes that the state was the proximate cause of the harm. These courts use the Martinez factors of foreseeability of harm, lapse of time, and agency in determining whether or not proximate cause exists, ${ }^{27}$ though foreseeability of harm, or the lack thereof, is generally the decisive factor. ${ }^{28}$ These lower courts give no explanation for their focus on causation rather than duty; they simply cite Martinez without comment. ${ }^{29}$

2. Duty. Courts that focus on duty rather than proximate cause typically analogize state inaction cases to a series of section 1983 cases brought by prisoners under the eighth amendment. ${ }^{30} \mathrm{In}$ Estelle v. Gamble, ${ }^{31}$ the Supreme Court held that prison officials could be held liable under section 1983 for displaying "deliberate indifference" to the medical needs of prisoners. Noting that the eighth amendment's prohibition of "cruel and unusual punishment"32 precluded the unnecessary and wanton infliction of pain, the Court concluded that deliberate indifference to a prisoner's serious illness or injury was constitutionally proscribed. ${ }^{\mathbf{3 3}}$ The Court's decision also rested on a concept of "fairness" that requires the state to take upon itself a special duty of protection when it imprisons a person and thereby deprives her of her ability to seek

${ }^{27}$ See, e.g., Humann v. Wilson, 696 F.2d 783, 784 (10th Cir. 1983) (lapse of only two months between transfer of inmate to low-security community center and rape of claimant held insufficient to distinguish case from Martinez); Estate of Gilmore v. Buckley, $608 \mathrm{~F}$. Supp. 554 (D. Mass. 1985) (liability denied on issue of causation), aff'd, 787 F.2d 714 (1st Cir. 1986).

${ }^{28}$ See, e.g., Humann, 696 F.2d at 784. But see Estate of Gilmore, 608 F. Supp. at 558 (liability denied despite alleged foreseeability of harm to murdered woman).

29 See, e.g., Humann, 696 F.2d at 784.

so For discussion of this development, see Jensen v. Conrad, 747 F.2d 184, 190-94 (4th Cir. 1984), cert. denied, 105 S. Ct. 1754 (1985).

s1 429 U.S. 97, 104-05 (1976).

32 U.S. Const. amend. VIII.

ss Estelle, 429 U.S. at 104 (quoting Gregg v. Georgia, 428 U.S. 153, 173 (1976) (joint opinion of Stewart, Powell, and Stevens, JJ.)). The concept of "deliberate indifference" has been further refined in subsequent cases. Deliberate indifference may be demonstrated either by a showing that prison officials intended to deprive the prisoner of a constitutional right or by a showing that they acted in "reckless disregard" of the prisoner's rights. See, e.g., Martin v. White, 742 F.2d 469, 474 (8th Cir. 1984). Reckless disregard, in turn, may be shown by "a pervasive risk of harm" to inmates and a failure to take reasonable measures in response to that risk. See Martin, 742 F.2d at 474; Withers v. Levine, 615 F.2d 158, 161 (4th Cir.), cert. denied, 449 U.S. 849 (1980); Woodhous v. Virginia, 487 F.2d 889, 890 (4th Cir. 1973). To show a "pervasive risk of harm," a claimant need not allege that a "reign of violence and terror" existed in the prison; it is sufficient that "an identifiable group of prisoners" fears for its safety. Withers, 615 F.2d at 161. 
help from other sources. ${ }^{34}$

Courts have justified their adoption of eighth amendment analysis for state inaction cases in several different ways. Some suggest that Estelle's emphasis on "fairness" demonstrates that the relationship between the state and an individual can create a duty of protection outside the prison context. ${ }^{35}$ This rationale has been used by the Second Circuit, for example, to find liability on the part of a state foster agency for its "deliberate indifference" to the continuing abuse of children under its supervision. ${ }^{36}$

Other courts have invoked the concept of detrimental reliance, hinted at by the Court in Estelle. ${ }^{37}$ In P.L.C. v. Housing Authority, ${ }^{38}$ a federal district court considered a claim for section 1983 relief brought on behalf of a woman who had been sexually assaulted by a Housing Authority maintenance employee. ${ }^{39}$ Despite its knowledge of his prior history of sexual assaults and alcoholism, the agency hired the man and provided him with a pass key to all of the apartments within the victim's apartment complex. The court noted that the state created the Housing Authority for the purpose of providing safe, sanitary housing for people in low-income groups. ${ }^{40}$ Granting recovery, the court concluded that the tenant had relied on the state for her housing and that a special relationship had thereby arisen between the state and the tenant."1

The Seventh Circuit, on the other hand, suggests that the relationship between the state and the victim or perpetrator of the harm creates a duty for the state to act when its inaction is tantamount to positive action. "If the state puts a man in a position of danger and then fails to protect him .... it is as much an active tortfeasor as if it had thrown him into a snake pit."42 However, if a person voluntarily assumes such a position of danger, section 1983 liability does not follow. ${ }^{43}$ Under this analysis, a state's duty to act

${ }^{34}$ Estelle, 429 U.S. at 103-04 ("An inmate must rely on prison authorities to treat his medical needs; if the authorities fail to do so, those needs will not be met. . . . ' $[\mathrm{I}] \mathrm{t}$ is but just that the public be required to care for the prisoner, who cannot by reason of the deprivation of his liberty, care for himself.' ") (quoting Spicer v. Williamson, 191 N.C. 487, 490, 132 S.E. 291, 293 (1926)).

ss See Jensen, 747 F.2d at 194.

${ }^{36}$ See Doe v. New York City Dep't of Social Servs., 709 F.2d 782, 790 (2d Cir.), cert. denied, 464 U.S. 804 (1983).

${ }^{37} 429$ U.S. at 103; see supra note 34.

ss 588 F. Supp. 961 (W.D. Pa. 1984).

39 Id. at 962 .

to Id. at 964 .

42 Id. at 965 .

42 Bowers v. DeVito, 686 F.2d 616, 618 (7th Cir. 1982).

43 See Walker v. Rowe, 791 F.2d 507, 511 (7th Cir. 1986) ("The state must protect 
arises when it places a person's life in jeopardy and does not provide her with some positive protection. ${ }^{44}$

Another factor considered by the courts is the state's declared intention to protect a certain individual or class of individuals. For example, a statute creating an agency to select and monitor the homes into which foster children are placed has been deemed evidence that a special relationship may exist between the state and the foster children. ${ }^{45}$

\section{B. Situations Involving No Special Relationship}

To understand more thoroughly the concept of special relationships, it is useful to examine cases in which courts have failed to find such a relationship. Many courts refuse to find such a relationship merely because the state has chosen to provide basic services to its citizens. ${ }^{46}$ Such an obligation, as Judge Posner has explained, would be inimical to the theoretical underpinnings of the Constitution:

[T] $T$ here is no constitutional right to be protected by the state against being murdered by criminals or madmen. It is monstrous if the state fails to protect its residents against such predators but it does not violate the due process clause of the Fourteenth Amendment or, we suppose, any other provision

those it throws into snake pits, but the state need not guarantee that volunteer snake charmers will not be bitten."); see also Rankin v. City of Wichita Falls, 762 F.2d 444, 449 (5th Cir. 1985).

14 This approach has led the Seventh Circuit to reaffirm its earlier decision granting recovery to claimants who, as young children, had been left stranded on a highway in the winter when police arrested their uncle and guardian. See Ellsworth v. City of Racine, 774 F.2d 182 (1985) (reaffirming White v. Rochford, 592 F.2d 381 (7th Cir. 1979)).

45 See Jensen v. Conrad, 747 F.2d 185, 195 n.11 (4th Cir. 1984), cert. denied, 105 S. Ct. 1754 (1985). Where the courts have discovered that a duty of protection does exist, they have generally undertaken a causation analysis as well. For example, the Fourth Circuit considered both duty and proximate cause when it concluded that an examination of the Martinez causation factors did not produce a clear-cut result. See Fox v. Custis, 712 F.2d 84, 87 (4th Cir. 1983). The court held that no state duty existed except when a special relationship existed between the state and the claimant. It then determined that no relationship could exist when the plaintiffs are simply members of the general public, and the state officials are " 'unaware that the [claimants] as distinguished from the public at large faced any special danger.' "Id. at 88 (quoting Martinez, 444 U.S. at 285) (footnote omitted). Thus, the court's proximate cause and duty inquiries both turned on the foreseeability of harm to the plaintiff. Id. at 88 n.3; see also Estate of Bailey v. County of York, 768 F.2d 503, 505-11 (3d Cir. 1985) (engaging in extensive duty analysis but ultimately deciding the case on proximate causation grounds).

4s See, e.g., Estate of Bailey, 768 F.2d at 511; Beard v. O'Neal, 728 F.2d 894, 900 (7th Cir. 1984); Wright v. City of Ozark, 715 F.2d 1513, 1516 (11th Cir. 1983); Jackson v. City of Joliet, 715 F.2d 1200, 1203-06 (7th Cir. 1983); Fox, 712 F.2d at 88. 
of the Constitution. The Constitution is a charter of negative liberties; it tells the state to let people alone; it does not require the federal government or the state to provide services, even so elementary a service as maintaining law and order. ${ }^{47}$

The state's decision to provide basic services to the general public thus does not obligate it to render assistance in any specific situation.

This understanding is a variation of the familiar principle that "the greater power includes the lesser power." ${ }^{48}$ On this reasoning, the state's acknowledged power to decide whether or not to provide certain basic services at all gives it impunity if it denies or fails to render services in a particular case. Under this approach, the question of whether any duty exists in a particular case turns on whether such a duty exists in general. ${ }^{49}$

This reasoning has led courts to deny recovery to claimants who allege that their injury was caused by the state releasing a prisoner on parole and then failing to supervise the parolee. ${ }^{50} \mathrm{Re}-$ covery has also been consistently denied when the plaintiff's injury is alleged to have resulted from inadequate government services, ${ }^{51}$ and when police officers or their agents are alleged to have failed to prevent an injury that occurred in their presence. ${ }^{.2}$ In one exem-

47 Bowers, 686 F.2d at 618.

${ }^{48}$ Cf. Myers v. United States, 272 U.S. 52, 177 (1926) (Holmes, J., dissenting) (referring to Congress's power to create the office of postmaster and reserve for itself removal power, Holmes wrote that "[w]ith such power over its own creation, I have no more trouble in believing that Congress has power to prescribe a term of life for it free from any interference than I have in accepting the undoubted power of Congress to decree its end").

19 For a criticism of this position, see infra notes 74-81 and accompanying text.

so See, e.g., Martinez v. California, 444 U.S. 277 (1980); Humann v. Wilson, 696 F.2d 783 (10th Cir. 1983); Bowers v. DeVito, 686 F.2d 616 (7th Cir. 1982); Estate of Gilmore v. Buckley, 608 F. Supp. 554 (D. Mass. 1985), aff'd 787 F.2d 714 (1st Cir. 1986). But cf. Beck v. Kansas Univ. Psychiatry Found., 580 F. Supp. 527, 533-34 (D. Kan. 1984) (plaintiffs stated a section 1983 cause of action against officials who released a prisoner who was known to pose a special danger to the decedents).

s1 For example, the Seventh Circuit has denied relief in two cases where plaintiff's injury resulted from the failure of rescue workers to prevent the kinds of harms they were hired to prevent. See Jackson v. Byrne, 738 F.2d 1443 (7th Cir. 1984) (recovery denied in section 1983 action arising from deaths of two children caused by fire that occurred during a firefighters' strike); Jackson v. City of Joliet, 715 F.2d 1200 (7th Cir. 1983) (recovery denied in section 1983 action involving deaths of two people from a car fire, where rescue workers failed initially to check the burning car for survivors).

${ }^{82}$ See, e.g., Beard v. O'Neal, 728 F.2d 894 (7th Cir. 1984) (FBI informant had no duty to prevent murder of plaintiff's decedent which occurred in his presence); Escamilla v. City of Santa Ana, 606 F. Supp. 928 (C.D. Cal. 1985) (undercover officers had no duty to intervene on behalf of innocent bystander who was killed during shooting incident). But see Byrd v. Brishke, 466 F.2d 6 (7th Cir. 1972) (police have duty to prevent plaintiff from being beaten by other police officers in their presence); Whirl v. Kern, 407 F.2d 781 (5th Cir. 1968) 
plary case, recovery was denied to a rape victim who alleged that the city had deliberately withheld information regarding a series of rapes in the area of town where she was attacked. ${ }^{53}$

\section{A CRItique}

\section{A. Causation}

Courts that place primary reliance on the concept of causation to determine section 1983 liability tend to confuse the proper analysis in two ways. First, they ignore vital interactions between causation, duty, and constitutional rights; in essence, they seem to believe that remote causation makes any inquiry into special relationship superfluous. Second, by focusing on causation, some courts recharacterize state inaction cases and implicitly force them into a state action analysis.

By concentrating on foreseeability of harm to demonstrate proximate cause, some courts ignore the critical initial inquiry in a section 1983 action-whether the alleged injury resulted from the state's deprivation of a constitutional right. ${ }^{54}$ State officials may be liable for their inaction only when they deliberately or recklessly fail to act. However, even where there is a deliberate failure to act that causes harm, state inaction will not be actionable unless there exists a duty to act-a duty that must arise under the Constitution. ${ }^{.5}$ Certain "undertakings" to provide protection may create an affirmative constitutional duty, but only if a principle can be found in the Constitution to impose that duty, not simply because the state is said to have "caused" the harm.

The logic of putting the issue of duty first is plain: if there is no right, there can be no constitutional duty to act; absent a duty, proximate causation becomes irrelevant. However, the converse does not follow; even where a general harm seems indirect or remote, courts may find a constitutional deprivation that is actionable under section 1983. Thus, the courts create two possible problems when they rely on causation to define actionable state

(sheriff breached his duty to ascertain the authority on which a prisoner was detained when the plaintiff was mistakenly held in the city jail for nine months after the charges had been dropped), cert. denied, 396 U.S. 901 (1969).

ss See Wright v. City of Ozark, 715 F.2d 1513 (11th Cir. 1983).

${ }^{34}$ See Baker v. McCollan, 443 U.S. 137, 140 (1979).

ss See, e.g., Walker v. Rowe, 791 F.2d 507, 511 (7th Cir. 1986).

so See Daniels, $106 \mathrm{~S}$. Ct. at 667 ("Jailers may owe a special duty of care to those in their custody under state tort law,. . . but for the reasons previously stated we reject the contention that the Due Process clause of the Fourteenth Amendment embraces such a tort law concept."). 
inaction: first, reliance on an elastic proximate cause determination could expand section 1983 liability to constitutionalize all of tort law; second, courts may fail to provide adequate protection against indirect deprivations of constitutional rights.

Even if the proper initial focus were on causation, the factor typically used by the courts to demonstrate proximate cause in state inaction cases-foreseeability of harm to a particular individual-is inapposite. Contrary to the suggestion in Martinez, ${ }^{57}$ the absence of foreseeable harm to a particular individual does not necessarily show a lack of proximate causation. Under the common law of tort, a finding of proximate cause need not be based on a foreseeable harm to a particular individual. ${ }^{58}$ Proximate cause is, as Justice Andrews declared, a matter of "practical politics." 59 Courts could reasonably decide that the foreseeability of a certain type of injury is more important than the foreseeability of harm to a particular person. Similarly, while courts might choose to impose liability for foreseeable harm to a particular individual, they might with just as much reason find a special relationship if there were foreseeable harm to a particular neighborhood. ${ }^{60}$ The larger the group to which a special duty is owed, the more it begins to resemble a duty to the public at large. Thus, causation analysis based on foreseeability could ultimately lead to a generalized duty of protection. $^{61}$

Primary focus on causation also could lead to an underinclusive interpretation of section 1983 . If courts reject claims on the basis of an initial analysis of causation, they may fail to recognize special relationships that would render even indirect causation actionable. ${ }^{62}$ Unless the courts examine the special relationships and

${ }^{87}$ Martinez, 444 U.S. at 285.

s8 See W. Keeton, D. Dobis, R. Keeton \& D. Owen, supra note 10, § 42, at 274-75.

s9 Palsgraf v. Long Island R.R. Co., 248 N.Y. 339, 352, 162 N.E. 99, 103 (1928) (Andrews, J., dissenting).

Bo See generally Prosser, Palsgraf Revisited, 52 Mrch. L. REv. 1 (1953) (discussing the problem of the unforeseeable plaintiff and its relation to causation and duty).

o1 The confusion that results from a failure to separate causation analysis from duty analysis is illustrated by the Fourth Circuit's opinion in Fox v. Custis, 712 F.2d 84 (4th Cir. 1983). The court recognized that both inquiries were necessary to determine liability, but diminished the value of this two-part inquiry by using the same standard-lack of foreseeability of harm-to prove both lack of causation and lack of duty. Id. at 87-88. The court simply proved the same point twice. Moreover, by relying solely on the traditional tort concept of foreseeability of harm, the court failed to ground its analysis of duty in the Constitution. $I d$.

${ }^{62}$ For example, consider Smith v. Wade, 461 U.S. 32 (1983), where the Supreme Court upheld liability against a prison guard for placing Wade in a cell with two other inmates who beat and sexually assaulted him. A Martinez-like causation analysis may have led to 
constitutional rights that are at stake, their attempts to analyze proximate cause are premature and incomplete.

Nor does a causation approach become less problematic if it is based on the well-developed principles of "state action." These principles are used in several areas of constitutional law to determine when individual action may be attributed to the state. ${ }^{63}$ If there is a sufficiently close "nexus" between the private actor's conduct and the state, then for constitutional purposes the state may be liable for the private actor's conduct. ${ }^{64}$ This principle might account for the preoccupation with causation and agency in some state inaction cases. Where a private third party murders a citizen, an in Martinez, it may seem necessary to impute the private party's action to the state in order to satisfy the requirements of the state action doctrine. Indeed, the Supreme Court took this tack in Martinez. Noting that the fourteenth amendment provides

the opposite result. Obviously, the inmates were not "agents of the [state]." Martinez, 444 U.S. at 285. And "[t]he mere placement of plaintiff in the cell with two others would not have given legal sustenance to his [section 1983] claim." Wade v. Haynes, 663 F.2d 778, 782 (8th Cir. 1981), aff'd sub nom. Smith v. Wade, 461 U.S. 32 (1983). The key to the court's resolution was its consideration of the special dependant relationship between the prison guard and Wade's rights under the eighth amendment to be free from cruel and unusual punishment. Without considering the particulars of this special relationship and Wade's vulnerablility to attack, the court might have dismissed the section 1983 action on causation grounds.

6s The Civil Rights Cases, 109 U.S. 3, 17 (1883) ("[C]ivil rights, such as are guaranteed by the Constitution against State aggression, cannot be impaired by the wrongful acts of individuals, unsupported by State authority in the shape of laws, customs, or judicial or executive proceedings. The wrongful act of an individual, unsupported by any such authority, is simply a private wrong, or a crime of that individual.").

The "state action" requirement of the fourteenth amendment duplicates the "under color of law" requirement of section 1983. See supra note 5. The doctrine was first enunciated in The Civil Rights Cases, 109 U.S. at 11 ("It is State action of a particular character that is prohibited [by the first section of the fourteenth amendment]. Individual invasion of rights is not the subject-matter of the amendment. . . . [It] nullifies and makes void all State legislation, and State action of every kind, which impairs the privileges and immunities of citizens of the United States, or which injures them in life, liberty or property without due process of law, or which denies to any of them the equal protection of the laws.").

" See Burton v. Wilmington Parking Auth., 365 U.S. 715, 724 (1961) (finding the required "nexus" where a private restauranteur leased space from a municipal parking authority and the restauranteur and parking authority conferred a wide variety of mutual benefits on each other so that the state could be said to profit from the discrimination). If the private entity performs a traditional "public function," such as running primary elections that effectively determine the outcome of the official election, see Terry v. Adams, 345 U.S. 461 (1953); Smith v. Allwright, 321 U.S. 649 (1944), or operating a private "company town" that has all the characteristics of an ordinary municipality, see Marsh v. Alabama, 326 U.S. 501 (1946), then its conduct may also be deemed state action and subjected to the proscriptions of the fourteenth amendment. But cf. Blum v. Yaretsky, 457 U.S. 991 (1982) (acts of private nursing homes that are heavily regulated and funded by the state are not state action). 
protection only against "state" action," the Court emphasized that because the parolee was not an agent of the state, his actions were not subject to constitutional scrutiny. ${ }^{66}$

The focus on agency is, however, misplaced: the state was being sued for its release of a dangerous parolee, not for a principalagent relationship with the parolee. ${ }^{67}$ The Court's analysis also conflates concepts of state action and causation. The Court disavowed reliance on state tort law, yet emphasized two factors-lapse of time and foreseeability of harm-that are typical of tort causation anaysis. ${ }^{.8}$

Moreover, this approach, like any that emphasizes causation, skirts the question of whether the state has a constitutional obligation to act in the first place. ${ }^{69}$ Even if the state can be said to have "acted," the important question is whether the state has acted consistently with the Constitution. Unless that question is deemed controlling, any state action that results in harm would give rise to section 1983 liability. ${ }^{70}$ Given the breadth of the states' regulatory capabilities, a causal connection between government inaction and private injury could be established for almost any "private" wrong. Yet it is inconceivable that any and all injuries caused by private individuals could be imputed to the state for the purposes of section 1983 liability. ${ }^{71}$

${ }^{65} 444$ U.S. at 284 (emphasis added).

${ }^{68} I d$. at 285.

67 See id. at $279-80$.

${ }^{68}$ See id. at 285.

${ }^{68}$ In many state inaction cases, the presence of "state action" is assumed without discussion. For example, in due process cases the state's failure to conform to the requirements of procedural regularity are usually found to violate the fourteenth amendment even though there is no explicit finding that the failure to hold an adequate hearing constitutes "state action." See, e.g., Goldberg v. Kelly, 397 U.S. 254 (1970).

${ }^{70}$ If a state fails, for example, to impose very stiff penalties on drunken drivers, then an accident victim might plausibly claim that he has been deprived of life or liberty without due process of law if he could show that the state's failure to regulate drunk driving caused his injury.

${ }^{71}$ See, e.g., Daniels v. Williams, 106 S. Ct. 662, 665 (1986) (to adopt such a position " "seems not only to trivialize, but grossly to distort the meaning and intent of the Constitution' ") (quoting Parratt v. Taylor, 451 U.S, 527, 545 (1981) (Stewart, J., concurring)). For one thing, this approach would allow federal courts to limit, through section 1983 liability, a state's ability to regulate its own internal matters, a problematic result. See Gibbons v. Ogden, 22 U.S. (9 Wheat.) 1, 203 (1824); see also PruneYard Shopping Center v. Robbins, 447 U.S. 74, 81 (1980) (state may exercise its police power to adopt constitutional liberties that are more expansive than the federal Constitution); City of New Orleans v. Dukes, 427 U.S. 297, 303 (1976) (the states are afforded wide latitude in regulating their local economy under the police power as long as rational distinctions are made); Hotel \& Restaurants Employees Int'l Alliance, Local 122 v. Wisconsin Employment Relations Bd., 315 U.S. 437, 442 (1942) (regulation of industrial relations is wholly within the state's police power, subject 
Causation analysis must, of course, remain a part of every section 1983 claim, but it should be separate from and subsequent to the duty inquiry. ${ }^{72}$ Only if a duty is found must the court inquire as to whether the state's failure to accomplish its duty caused the injury in question. If the state is found to have a constitutional duty of protection, it cannot be held liable unless its breach of that duty bears some causal relation to the harm. This follows both from the language of section $1983^{73}$ and from rudimentary principles of liability; even in actions based on strict liability, causation must be shown. ${ }^{74}$

\section{B. Duty}

A tort-based special relationship that creates a duty to act is likewise not an adequate constitutional source for obliging the state to act; the constitutional underpinnings of the "special relationship" concept as currently applied are tenuous. The Court repeatedly has expressed concern that expansive constitutional duties may threaten to supplant traditional tort law or trivialize constitutional provisions. ${ }^{75}$ Thus, the notion that the relationship

only to federal constitutional restrictions).

It should be noted that the state action doctrine limits only the ability of the federal courts to usurp the state's police power by regulating private conduct via section 1983 liability. Congress, however, may have the authority to regulate private conduct under section 5 of the fourteenth amendment, which empowers it to enforce the amendment by appropriate legislation. U.S. CoNsT. amend. XIV, \& 5; see Katzenbach v. Morgan, 384 U.S. 641, 646 (1966) (upholding section 4(e) of the Voting Rights Act of 1965 as a valid exercise of congressional authority under section 5 of the fourteenth amendment); United States v. Guest, 383 U.S. 745, 762, 777, 779 (1966) (acknowledging Congress's power to reach purely private conduct by virtue of its authority under section 5). Thus, Congress may regulate private conduct directly, but the courts, without congressional authorization, may not.

Because Congress may reach discriminatory conduct directly via section 5 , one might conclude that section 1983, as an enactment of Congress, delegates to the courts the authority to reach purely private conduct. However, the Court has recognized that Congress alone was given this special authority to enforce the amendment. See, e.g., Katzenbach, 384 U.S. at 648 . To interpret section 1983 so that it reaches purely private conduct would give the courts the authority to "amplify prohibitions of the Constitution," an authority that cannot be found even on the broadest reading of the cases construing section 5. See Frantz, Congressional Power to Enforce the Fourteenth Amendment Against Private Acts, 73 Yale L.J. 1353, 1356-57 (1960).

72 See Eaton, Causation in Constitutional Torts, 67 IowA L. REv. 443, 479 (1982) ("Resolving the threshold question of duty in terms of causation can only confuse both issues. [Courts should] recognize the distinction between duty and causation and analyze each in its own terms.").

7342 U.S.C. $\S 1983$ (1982) ("subjects or causes to be subjected . . . to the deprivation of any rights, privileges, or immunities secured by the Constitution and laws").

74 See W. KeEton, D. DobBs, R. KeEton \& D. OWEN, supra note 10, § 79.

7s See, e.g., Daniels v. Williams, 106 S. Ct. 662, 666 (1986) ("Our Constitution deals 
between the state and the victim or perpetrator of an injury can give rise to a constitutional duty must be grounded in the Constitution itself.

Some courts have attempted to provide a constitutional framework for the emphasis on special relationships in state inaction cases by drawing an analogy to Estelle, a case brought by a prisoner. State inaction in a prison environment may violate the eighth amendment because the state has a duty not to impose cruel and unusual punishment. The "special relationship" between the prisoner and the state, that of prisoner and jailer, is important because it activates a constitutional prohibition that is otherwise inapplicable. ${ }^{78}$ But eighth amendment analysis is not easily translated to fourteenth amendment cases outside the prison context; the eighth amendment has no force in relationships between the state and nonprisoners. ${ }^{77}$

Nevertheless, some state inaction cases derived from Estelle point to "fairness" as dictating that where a state has taken aggressive action that reduces an individual's ability to help herself, the state must take upon itself an affirmative duty to protect that individual. ${ }^{78}$ This analysis is also problematic. Vague notions of "fairness" give a result an equitable basis, not a constitutional one. The duty must be found in the Constitution. ${ }^{79}$

Other cases have adopted a "position of danger" exception to the general rule that a state has no duty to act. They rely not on Estelle's reference to "fairness," but rather on the understanding that a state's inaction approaches positive action when it places a person in jeopardy and then fails to protect her. ${ }^{80}$ This approach, however, aptly applies only to a limited number of cases. The "position of danger" exception is properly interpreted as placing on state agents a duty of protection only when they or other state agents have jeopardized someone's safety. ${ }^{81}$ Otherwise the "posi-

with the large concerns of the governors and the governed, but it does not purport to supplant traditional tort law."); Paul v. Davis, 424 U.S. 693, 701 (1976).

${ }^{70}$ Estelle, 429 U.S. at 104.

77 See Ingraham v. Wright, 430 U.S. 651, 669-70 (1977) (finding corporal punishment in schools beyond the reach of eighth amendment).

${ }^{76}$ See supra notes 35-36 and accompanying text; cf. Estelle, 429 U.S. at 104.

72 E.g., Daniels, 106 S. Ct. at 666.

so See supra notes $37-45$ and accompanying text.

81 See, e.g, White v. Rochford, 592 F.2d 381, 384 (7th Cir. 1979) (police officers had a duty to protect minor children from immediate hazards after they arrested the children's guardian); Byrd v. Brishke, 466 F.2d 6, 11 (7th Cir. 1972) (police officers had a constitutional duty to help a person who was being beaten in their presence by other police officers).

Some decisions have made the "position of danger" exception appear to apply in more 
tion of danger" theory fails to carve out an appropriately delimited exception to the general rule that the state is under no duty to act. In theory, of course, a state could be held to place a person in a "position of danger" whenever it encourages her to rely on a particular governmental service for her well-being and protection; in such a situation, the citizen is in a "position of danger" by virtue of her reliance on the government's continued support and protection. Courts applying this standard fail to explain why this kind of reliance is constitutionally irrelevant.

Even if detrimental reliance were recognized as the basis of the state's duty to protect its citizens, tort concepts of special relationships would fail to provide the necessary constitutional foundation for the duty to be actionable under section 1983. Even the "position of danger" approach requires some constitutional principles to guide the determination of when an individual's reliance on the state is proper. Simple reference to the tort concept of a reasonable man, for example, might provide a ready answer to the problem of defining appropriate reliance, but it does not speak to the problem of defining constitutional rights and duties. For that, one must turn to the due process clause. ${ }^{\mathbf{2 2}}$

\section{State Inaction as a Violation of Due Process}

The courts have struggled with the issue of imposing liability for state inaction because they have failed to identify any workable constitutional standard. But in fact the Supreme Court developed such a standard when it set forth the due process requirements for the withdrawal of statutory entitlements. Even assuming that a state has no obligation to provide protection in the first place, it may violate the due process clause when it assumes such an obligation and then fails to fulfill it. In many inaction cases, the state has done just that.

situations by citing cases which principally relied on the eighth rather than the fourteenth amendment. See Bowers v. DeVito, 688 F.2d at 618; Ellsworth v. City of Racine, 774 F.2d at 185.

22 A constitutionalized duty under the due process clause differs from a tort duty in one critical respect-it requires an affirmative undertaking by the state before the obligation becomes effective. By contrast, a tort "special relationship" often arises simply from the nature of the relationship between the two parties, without any affirmative obligation ever being explicitly undertaken. See, e.g., Kline v. 1500 Mass. Ave. Apartment Corp., 439 F.2d 477 (D.C. Cir. 1970) (relationship between landlord and tenant); Hutchinson v. Dickie, 162 F.2d 103 (6th Cir. 1947) (host and guest); Stachniowicz v. Marcamy, 259 Ore. 583, 488 P.2d 436 (1971) (bar owner and patron); Lee v. National League Baseball Club, 4 Wis. 2d 168, 89 N.W.2d 811 (1958) (baseball team and paying spectator). 
This section identifies the cases in which state inaction may be challenged under the due process clause. Under the framework sketched here, three considerations are relevant to inaction claims: whether the state has created a protected property interest; what kind of procedural safeguards attach to that property interest, given the relative interests of the state and the individual; and what remedy, if any, the individual is entitled to have when those procedures are not given. Through this framework, it is possible to show which kinds of inaction claims are likely to present remediable constitutional violations.

\section{A. Due Process Limits to State Inaction}

1. Entitlements and Reliance. In Goldberg $v$. Kelly, ${ }^{83}$ the Supreme Court held that welfare recipients are entitled to evidentiary hearings before a state may terminate their benefits. The Court's conclusion relied on a fundamental distinction between two kinds of obligations on the state: a requirement that the state provide welfare benefits in the first place, and the requirement that, once the state provides benefits of its own accord, it administer them fairly. Although the Court acknowledged that nothing in the Constitution imposes the first obligation on states, the due process clause does impose the second..$^{84}$ Once a state statute promises benefits to a certain class of individuals, the state must comply with standards of due process in determining which individuals fall within that class.

ss 397 U.S. 254, 261 (1970).

84 Id. at 261-62 ("Appellant does not contend that procedural due process is not applicable to the termination of welfare benefits. Such benefits are a matter of statutory entitlement for persons qualified to receive them. Their termination involves state action that adjudicates important rights. The constitutional challenge cannot be answered by an argument that public assistance benefits are "a "privilege" and not a "right".' ") (quoting Shapiro v. Thompson, 394 U.S. 618, 627 n.6 (1969)) (footnotes and citations omitted); see also Reich, The New Property, 73 YaLE L.J. 733 (1964).

Some scholars argue that states may have a duty to provide certain benefits in the first instance. See, e.g., Michelman, Foreword: On Protecting the Poor Through the Fourteenth Amendment, 83 HaRv. L. REv. 7 (1969); Miller, Toward a Concept of Constitutional Duty, 1968 Sup. CT. REv. 198. And some of the Supreme Court's decisions might be read to support that position. See, e.g., Truax v. Corrigan, 257 U.S. 312, 327-28 (1921) (state must provide injunctive remedy for labor picketing); Bronson v. Kinzie, 42 U.S. (1 How.) 311,320 (1843) (state cannot erase foreclosure rights of mortgagee by denying him an adequate contractual remedy). But cf. San Antonio Indep. School Dist. v. Rodriguez, 411 U.S. 1 (1973) (rejecting claim that plaintiffs have a constitutional right to education). This comment neither considers nor relies upon such an interpretation of the Court's cases. For a thorough discussion of many such cases, see Currie, Positive and Negative Constitutional Rights, 53 U. ChI. L. REv. 864 (1986). 
According to the Court, the extent of the due process protection that is available depends on two things: the nature of the entitlement claimed and the interests of both the state and the individual in accuracy-enhancing procedures. The nature of the entitlement is important because the due process clause affords protection only to entitlements that can be considered "property" interests. An "abstract need or desire," the Court said, does not constitute property. ${ }^{85}$ Instead, property interests "are created . . . by existing rules or understandings that stem from an independent source such as state law-rules or understandings that secure certain benefits and that support claims of entitlement to those benefits." ${ }^{\text {B8 }}$ Hence, due process safeguards do not exist to protect benefits for their own sake, but rather to protect the expectation a state creates by making promises on which individuals rely; in short, the Court has held that a state acts unfairly when it arbitrarily goes back on its promises. ${ }^{87}$

Because the due process clause defines "property" in light of the expectation created by the state, and not according to the quality of the entitlement, property interests may exist in promises to provide services that would not be considered property in a more traditional sense of the term. For example, the Supreme Court has held that individuals have property for due process purposes in a driver's license, public education, or even a cause of action itself, where state law specifies that such benefits will be conferred on certain classes of persons. ${ }^{\mathrm{gs}}$

For different "property" interests, however, due process may impose different procedural requirements. The degree of protection that is required in any given case depends on three factors: the magnitude of the individual's interest, the risk of an inaccurate decision if a procedure is not provided, and the state's interest in withholding the procedure because of the expenditures it would require $^{89}$ Due process requires additional procedures when the costs

${ }^{8 s}$ Board of Regents v. Roth, 408 U.S. 564, 577 (1972).

so Id.

"Id. (the institution of property, and thus the importance of due process, is "to protect those claims upon which people rely in their daily lives").

so See Bell v. Burson, 402 U.S. 535, 539 (1971) (driver's license); Goss v. Lopez, 419 U.S. 565, 573 (1975) (public school); Logan v. Zimmerman Brush Co., 455 U.S. 422,437 (1982) (statutory right to timely hearing).

so See Mathews v. Eldridge, 424 U.S. 319, 335 (1976); see also Morrissey v. Brewer, 408 U.S. 471 (1972) (parolees may not be reincarcerated without a hearing); Fuentes v. Shevin, 407 U.S. 67 (1972) (the state may not seize property that is in one person's possession upon application of another person without first providing a hearing); Sniadach v. Family Finance Corp., 395 U.S. 337 (1969) (debtors are entitled to a hearing before private creditors can 
of inaccuracy to the individual outweigh the state's interest in summary adjudication. In Goldberg, for example, the consequences of an inaccurate termination of subsistence benefits were so large that the Court required "some kind of hearing" before termination..$^{90}$

2. Inaction As Withdrawal of an Entitlement. Many inaction cases present the same kind of due process concerns identified by the Court in Goldberg. In both inaction cases and entitlement cases, the state has promised to provide a benefit, thereby inducing reliance by its citizens. And in both cases the government has withheld the benefit from a particular individual without first determining in an appropriate manner whether the individual falls outside the class of people who are entitled to the benefit under state law. Analytically, Goldberg-like entitlement cases and state inaction cases are identical; the constitutional safeguards required in the former should be provided in the latter. ${ }^{91}$

A Goldberg due process approach will add analytical clarity to inaction cases. First of all, it frees courts from dependence on unhelpful tort principles. State liability for inaction will be considered as a matter of articulable standards in state law, not according to perplexing notions of "duty" or "proximate cause."

Second, by grounding liability for inaction in the due process clause, this approach does not construe the Constitution to impose positive obligations on states. As in Goldberg, the question is not

enlist the state's help in taking possession of their property); Sherbert v. Verner, 374 U.S. 398 (1963) (disqualification for unemployment compensation requires a hearing); Speiser v: Randall, 357 U.S. 513 (1958) (denial of a tax exemption requires a hearing).

${ }^{90}$ Parratt v. Taylor, 451 U.S. 527, 540 (1981).

91 The liberty interest protected by the fourteenth amendment will not, standing alone, afford a constitutional basis for recovery under section 1983 when the claim is grounded on the state's inaction. An individual's right to freedom from bodily restraint or harm is certainly a "liberty." See Board of Regents v. Roth, 408 U.S. 514, 573 (1972) (quoting Meyer v. Nebraska, 262 U.S. 390,399 (1923)). However, in most instances the "state action" doctrine will preclude recovery from a state for an injury of this nature inflicted by a third party.

Take, for example, the victim of a random mugging on a city street. Clearly, the victim has been deprived of his liberty interest in freedom from bodily restraint. But here there is no state action that precedes the injury. This state of affairs contrasts sharply with the "property" context, where the state has previously acted by conferring a benefit. There the state's refusal to act to prevent the withdrawal of benefits becomes culpable precisely because of its original action.

One might further argue, however, that the state has performed an act antecedent to the mugging; it has, after all, provided a police force. But then the inquiry into the liberty interest collapses back into an analysis of the property interest. The proper questions to be asked are whether a state has limited its discretion by making a promise of services or of protection and whether the state has withdrawn the benefits of such a promise without due process of law. See infra notes 90-99 and accompanying text. 
whether government benefits are constitutionally required in the first instance, but under what circumstances those benefits, once conferred, may be constitutionally withdrawn. On this view, the "greater" power to deny all benefits does not include the "lesser" power to withdraw benefits arbitrarily. Likewise, under a due process approach the Seventh Circuit's defense of inaction has no force; the state's failure to follow through on its promises is fundamentally different from the failure to act when no promise was made. ${ }^{82}$

\section{B. Applications}

Under Goldberg's due process framework, the question of whether any given instance of state inaction violates the Constitution depends first on whether the plaintiff had a property interest in the state's promised action. If the plaintiff claims a legitimate property interest, the court must determine whether state procedures were inadequate. If a due process violation is established, the court must then determine what remedy is appropriate. ${ }^{93}$

92 In Goss, 419 U.S. at 574, the Court rejected dicta from the plurality opinion in Arnett v. Kennedy, 416 U.S. 134, 154 (1974), which suggested that plaintiffs whose statutory benefits are cut off without due process "must take the bitter with the sweet." Instead of adopting the rationale offered by the Arnett plurality, that a "grant of a substantive right is inextricably intertwined with the limitations on the procedures" laid out in a statute, $i d$. at 153, the majority in Goss held that statutory entitlements may not be withdrawn "absent fundamentally fair procedures to determine [the grounds for termination]," 419 U.S. at 574 .

os It might be argued, incorrectly, that a section 1983 suit in federal court cannot be a proper remedy for the state's alleged violation of the individual's due process rights as long as the state provides an adequate postdeprivation remedy. In Parratt v. Taylor, 451 U.S. 527 (1981), for example, the Supreme Court held that a state official's negligent deprivation of an individual's property might be actionable under section 1983 , but only where the state did not provide an adequate postdeprivation remedy. The case involved only a hobby kit worth about 23 dollars, and accordingly it has been interpreted by some lower courts to apply only to insignificant claims. See, e.g., Gilmere v. City of Atlanta, 774 F.2d 1495, 1498 n.3 (11th Cir. 1985) (en banc).

It would be very difficult, moreover, to read such a bar into section 1983. The purpose of that provision was to provide a federal cause of action and a federal forum for citizens who suffer a "deprivation" of their constitutional rights. 42 U.S.C. $\$ 1983$. It is irrelevant to this purpose whether the states may provide some form of alternative remedy; the statute grants plaintiffs access to a federal forum in which to bring their claims if they choose to avail themselves of it. The same holds true for due process claims in particular; the only new element involved in these claims is the separate determination of what process is "due" or adequate to prevent a constitutional violation altogether. Where the section 1983 claim is grounded on state conduct that was more egregious than mere negligence, and where predeprivation procedural protections are practicable, see infra note 99; see also infra text following note 98 , postdeprivation remedies can no longer be considered adequate absent some exigency, see Parratt, 451 U.S. at 537-41. See also Monaghan, State Law Wrongs, State Law Remedies, and the Fourteenth Amendment, 86 Colum. L. Rev. 979, 988-89 (1986) (noting that Paratt held that postdeprivation procedures are constitutionally rele- 
1. Property in Promised Action. The inaction cases discussed in Part I provide good examples of the kinds of property interests that may arise from government promises. Under some state statutes, for example, foster agencies are directed to place foster children in safe, adequate homes and to ensure that the homes continue to be safe. ${ }^{94}$ Foster children benefit from such statutes, and, in a sense, rely on the state's promise to provide continuing protection. When the state deprives an individual foster child of this protection by failing to monitor the foster home's safety, the child may claim that she has been deprived of property. Moreover, any child may benefit from a statute that creates agencies to report and prevent cases of child abuse; ${ }^{95}$ if the state fails to carry out the statutory directives, a child may be deprived of her property interest in this protection. Similarly, a tenant in public housing receives benefits from a statutory or administrative command that buildings be maintained safely; $;^{96}$ the tenant may be deprived of a property interest when such protection is withdrawn.

Whether direct or implied, the state's promise itself usually limits the property interest it creates. For example, an informant may agree to give testimony for the state in exchange for the

vant only where predeprivation procedures are infeasible). In such circumstances, a plaintiff has been deprived of property without due process of law, and it does not matter whether it is conceivable that the state might later restore the property on its own initiative; the deprivation without due process serves as the basis for the federal cause of action. Cf. Daniels, $106 \mathrm{~S}$. Ct. at 664-66 (holding that a section 1983 claim based on an alleged due process violation cannot be grounded on mere negligence because such conduct does not amount to a "deprivation").

In addition, it should be noted that the vitality of Parratt is in question insofar as the Court's most recent $\S 1983$ decisions ignored the issue of postdeprivation remedies to focus instead on actionable states of mind. See Daniels, 106 S. Ct. 662 (overruling Parratt to the extent that mere negligent conduct had been deemed sufficient to violate the due process clause); see also Davidson v. Cannon, 106 S. Ct. 668 (1986).

of See Doe v. New York City Dep't of Social Servs., 709 F.2d 782, 791 (2d Cir.) (New York's Social Service Law requires social workers to report all suspected child abuse to the State Department of Social Services), cert. denied, 464 U.S. 864 (1983).

ss See Jensen v. Conrad, 747 F.2d 184, 185, 188 (4th Cir. 1984) (South Carolina's Protection Act imposes upon the State Department of Social Services a duty to coordinate child protection services throughout the state), cert. denied, $105 \mathrm{~S}$. Ct. 1754 (1985); cf. Estate of Bailey v. County of York, 768 F.2d 503, 505 (3d Cir. 1985) (York County Children and Youth Services is authorized under Pennsylvania's Child Protective Services Law to seek judicial determination of the need to place an abused child in protective custody and to appoint a guardian ad litem for the child). But cf. Taylor v. Ledbetter, 791 F.2d 881, 882 (11th Cir. 1986) (finding no substantive interest protected by the Constitution where the state only provided that certain procedural guidelines were to be followed in reaching decisions about benefits to particular children).

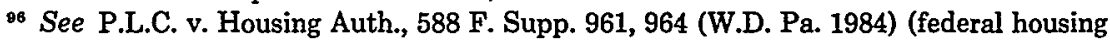
authority law declares provision of safe and clean housing to the poor as purpose of the statute). 
state's promise of protection. Such a promise can create a property entitlement even though it is individualized and does not confer the benefit upon a more general class of persons. But the state may promise very limited protection, for example for only eight hours a day. ${ }^{97}$ Since no property right in protection is created during other periods, any injury that occurs at those times does not result from deprivation of "property."

Some inaction cases involve government benefits that do not rise to the level of property interests. Property interests in government benefits are created by statutes limiting the discretion of government officials, statutes which dictate that benefits be given once it is found that a particular individual falls within the designated class of beneficiaries. Laws creating police forces, for example, do not limit discretion in this way. They do not specify a particular class of citizens that is to benefit specially from police protection, nor do they limit the state's discretion in deciding when to provide such protection; rather, such laws are designed to provide protection on a general basis and not to any particular individual or class. ${ }^{98}$ This kind of statute does not create a property

${ }^{97}$ Ellsworth v. City of Racine, 774 F.2d 182, 183 (7th Cir. 1985). The Seventh Circuit rejected the claim entirely, see id. at 186, instead of looking at the specific terms of the state's promise.

- See Stewart and Sunstein, Public Programs and Private Rights, 95 HARv. L. Rev. $1195,1271-75$ (1982) (discussing refusal of courts to recognize private rights to regulatory benefits in the context of administrative law).

This point should not be confused with the principle that due process does not require a hearing where the state action affects a large number of citizens or the community as a whole, whose complaints may be more properly addressed through the political process. See Bi-Metallic Investment Co. v. State Bd. of Equalization, 239 U.S. 441, 445-46 (1915); cf. Londoner v. City of Denver, 210 U.S. 373, 385-86 (1908) (requiring a hearing where the property rights of a small number of citizens were affected by the state's action and where the issues relevant to the government's decision would be resolved by considering individualized facts). The view that individualized hearings enhance the accuracy of factual determinations only when the facts at stake are particularized or not wholly generalizable also serves as the rationale for the distinction that is made in administrative law between legislative and adjudicative facts. See 1 Kenneth Davis, Administrative Law Treatise $\$ 7.02$ (1958).

In Bi-Metallic, the existence of a traditional property right was unquestioned; the state sought to increase the valuation of a taxable property in Denver and to increase taxes on that basis. 239 U.S. at 443 . The only issue was whether an individualized hearing was necessary in order adequately to protect that interest. In state inaction cases involving general government protections, on the other hand, individuals cannot even make out a claim that they have a property interest in the protection. In sum, in Bi-Metallic cases, no hearing is required because the political process provides all the process that is due; in state inaction cases complaining of inadequate police protection, no hearing is required because police protection does not constitute "property."

$B i-M e t a l l i c$ and state inaction cases involving benefits conferred on the public at large are similar in one respect. Both direct the litigants'complaints to the political process. While 
interest for a particular individual that could be invoked in a section 1983 case.

2. Procedural Protections Before Inaction. Although the property interests created by state law may be extensive, not all of them carry broad procedural protections. As Goldberg teaches, in an inaction case the question is whether the withdrawal of services was accompanied by procedures that were sufficient to ensure consistency with state law. In other words, given the relative interests of the state and the individual, did the state adequately consider whether the individual fell outside the class of persons who are entitled to protection under state law?

From an individual's perspective, inaction by the state often threatens to injure individuals at least as severely as did the withdrawal of benefits in Goldberg. For example, a foster child deprived of adequate supervision may face grave injury or death. Hence, barring a significant state interest in summary adjudication, some type of Goldberg procedures would have to precede deprivation of this service.

The state may, of course, be completely unable to provide predeprivation procedures where the deprivation results from negligence by its agents. Where a promised benefit is denied inadvertently, the need for accuracy-enhancing procedures simply cannot be predicted. Nor would such procedures be at all meaningful, since the state is not really "deciding" that the individual falls outside the class of protected persons. According to this theory, therefore, negligent inaction by the state should not trigger liability under section 1983; for due process to attach, the state or its agent must act either intentionally or recklessly to withdraw protection.98

some might question the harshness of this result, one can only reply that greater sensitivity cannot be found in the Constitution. See Bowers v. DeVito, 686 F.2d 616, 618 (7th Cir. 1982) ("it is monstrous if the state fails to protect its residents . . . but it does not violate the due process clause of the fourteenth amendment"). The extent of the state effort to provide protection to its citizens-how much, for example, to spend on the police force-will remain, ultimately, a question to be resolved by the political process. Imposing such duties upon the states as a constitutional matter, where they have not imposed them on themselves, is not within the powers of the courts.

${ }^{99}$ This conclusion is in harmony with the result reached in the two most recent Supreme Court decisions in this area. See Davidson v. Cannon, 106 S. Ct. 668, 670 (1986); Daniels v. Williams, 106 S. Ct. 662, 663 (1986).

It is also extremely important to differentiate between the state's intentional or reckless withdrawal of promised protections and intentional or reckless actions by state agents that in themselves amount to constitutional deprivations. It will typically be much more difficult for the state to prevent the latter from occurring than to prevent the former. For example, in Hudson v. Palmer, 104 S. Ct. 3194 (1984), prison guards were alleged to have intention- 
Even where the balance of interests favors some procedural protections, the protections required may look quite different from the evidentiary hearing ordered in Goldberg. Often it will be quite easy to determine whether an individual falls within the class of persons who are entitled to rely on the state's self-imposed obligation to act; for example, it is easy to identify foster children who have been explicitly granted certain kinds of protection by the state. Since such a decision does not involve factual determinations that are best made in a full hearing, a state need only provide enough procedure to make the decision reasonably accurate. At the same time, if the correct decision is plain, evidence that the state incorrectly decided it will probably suffice to show that the procedures were inadequate. Moreover, in the state inaction cases principally discussed in this comment, the complaint is not simply that the state provides inadequate procedures, but that it provides no procedural protection at all.

3. Remedy. In most inaction cases, the plaintiff seeks compensation for all injuries "caused" by the state's failure to act. Where the state's obligation under section 1983 is determined by tort principles, this remedy is uncomplicated; the state will be liable to the same extent as any tortfeasor. Basing the claim on due process, however, implies a somewhat different remedial approach. In tort law, the state would be fully liable because it had a duty to prevent the injury itself; under the due process clause, the state is obliged only to provide procedures that might have prevented the injury by affording state protection.

In most cases, the two approaches will lead to the same remedy. For the purposes of money damages, section 1983 makes the state liable for the consequences of the constitutional deprivation. ${ }^{100}$ Where procedures would have resulted in the state conferring the benefit it promised, the state is liable to the full extent of

ally seized and destroyed property belonging to a prisoner. Confronted with an action under $\S 1983$, the Court held that state postdeprivation procedures were adequate to redress the harm, resting largely on its judgment that the state, which could not predict the random intentional acts of its agents, had no way to afford meaningful predeprivation procedures to avoid the harm. Id. at 3203 ("Whether an individual employee is able to foresee a deprivation is simply of no consequence. The controlling inquiry is solely whether the State is in a position to provide for predeprivation process."). In contrast, the state usually will find it relatively easy to provide enough procedures to determine whether an individual is entitled to promised protections before they are withdrawn; this determination often can be made simply as a matter of following minimal and established procedures.

${ }^{100}$ See 42 U.S.C. $\$ 1983$ (1982) (making the injuring party liable "for redress"); Carey v. Piphus, 435 U.S. 247, 257 (1978) ("damage awards under $\S 1983$ should be governed by the principles of compensation"). 
the injury that would have been prevented. For example, a foster child who would have been saved from abuse had the state adequately considered its decision to withdraw promised protection would be able to recover for all injuries resulting from the abuse.

Recovery may be denied for lack of causation in due process cases, just as in tort cases. Often the property deprived-the state's protection-would not have prevented the injury. This will be true where the individual did not in fact rely on the state's promise. Although there may be injury even where the plaintiff did not expect the state's protection, the injury is not a consequence of the state's failure to provide due process.

This limitation presents no obstacle where reliance is obvious. For example, foster children brought within the state's protection involuntarily have no choice but to rely on the state's promise. They cannot seek outside help or protection. But where the individual's reliance on the government is not involuntary, it may be less than certain whether the injury resulted from the individual's expectation of protection. For example, a state's practice of reporting crime to its citizens might create a property interest in being made aware of dangerous areas. ${ }^{101}$ Where the government deliberately withholds such information, and a citizen is assaulted, the citizen may have been deprived of property without adequate procedures. But since the deprivation of the property interest must cause the injury in question, the injured citizen must prove that she in fact relied upon police reports and altered her conduct accordingly. If the individual did not expect the state's protection, her injury did not result from loss of a property interest within the meaning of due process. ${ }^{102}$

\section{Conclusion}

A close analysis of state inaction claims under section 1983 shows why the approaches taken by most courts are incorrect or superficial. Courts that look to tort concepts like causation and duty fail to articulate any constitutional standard for state liability. Courts that hold that the Constitution never requires states to provide affirmative protections ignore due process limitations on the withdrawal of promised entitlements. A due process approach changes the analysis of such claims significantly. The questions be-

101 See Wright v. City of Ozark, 715 F.2d 1513, 1514 (11th Cir. 1983).

${ }^{102}$ At a minimum, however, the injured citizen should be afforded an opportunity to demonstrate this reliance-the summary disposition that is currently typical for such claims is wholly inappropriate. See, e.g., id. 
come whether the plaintiff can show a property entitlement arising from his reliance on a promise by the state, and whether the state provided adequate procedural protections to justify inaction that injured the plaintiff by depriving him of that property.

This approach makes it possible to draw distinctions between different kinds of inaction claims that have caused the most difficulty for the courts. For example, foster children who were denied adequate supervision by the state may have promising due process claims that entitle them to money damages under section 1983. Many such children will be able to show actual reliance on a clear statutory promise, and the property interest created therein more than outweighs the costs of procedural safeguards necessary to protect against its improper deprivation. Other claims, like those of tenants injured in public housing, will be more difficult to prove. These plaintiffs will have to present evidence of actual reliance on an explicit state promise of protection. Finally, some broader inaction claims will fail to state a cause of action under section 1983, such as when the plaintiff demands a benefit that has not been given in a manner that limits the state's discretion. Under this approach, a state will not be liable for every instance of inaction. But when the state by its inaction has broken its own promise, it may not escape liability by invoking an artificial distinction between action and inaction. 